\title{
DIRETRIZES PARA AUTORES
}

\section{Normas de submissão}

Os artigos e resenhas submetidos ao periódico RACE (Revista de Administração, Contabilidade e Economia) devem obedecer aos critérios aqui elencados.

a) Cada autor pode submeter 1 (um) artigo por ano ao periódico.

b) A exatidão das referências e as ideias expressas e/ou defendidas nos textos são de inteira responsabilidade dos autores; estes ao submeter o artigo, deverão aceitar a Declaração de Direitos Autorais.

c) Serão aceitos artigos em português e em inglês.

d) O texto deve passar por revisão linguística antes de ser submetido.

e) OEditor Científico do periódico e a Editora Unoesc não se responsabilizam pelo extravio ou eventual perda de material, devendo o autor manter cópias do original.

f) Os trabalhos devem ser submetidos no endereço eletrônico da Revista: http://editora.unoesc.edu.br/index.php/race/index em formato.doc.

g) $\mathrm{O}$ artigo deve ser inédito, se enquadrar no foco, escopo e linha editorial da Revista, estar em conformidade com as normas da ABNT, e não pode estar em avaliação em outra revista concomitantemente.

A Revista Race não recebe artigos apenas de revisão da literatura, sendo que os textos submetidos devem comportar ou estudos teóricos densos ou estudos teóricoempírico que contribuam para a área da Administração, Contabilidade e/ou Economia.

Os textos serão submetidos à apreciação do corpo editorial, com a omissão do nome do autor e dos avaliadores durante o processo double blind review (o autor não sabe quem é o avaliador e este também desconhece quem é o autor).

Após o processo, caso haja necessidade, os avaliadores proporão alterações, visando à melhora do trabalho, com o objetivo de publicá-lo. Se as alterações não 
forem realizadas a contento e no prazo estipulado, os avaliadores podem rejeitar o artigo.

Após a avaliação, os artigos serão encaminhados à Editora para os processos de revisão, normalização e formatação, conforme as normas da ABNT. O trabalho dos autores e dos consultores não será remunerado.

Todos os autores-doutores do artigo submetido comprometem-se automaticamente a atuar como avaliadores de outros artigos submetidos à revista nas respectivas áreas de domínio de conhecimento.

A Revista é publicada em formato eletrônico (PDF), disponibilizado pela internet na página da Revista e/ou na(s) página(s) do(s) indexador(es).

A Revista permitirá o acesso aos artigos, resenhas e demais textos, não autorizando qualquer comercialização e/ou alteração dos dados. Desse modo, o(s) autor(es) fica(m) ciente(s) da cessão de seus direitos autorais de publicação à Revista.

Os artigos devem ser elaborados em folha formato A4, margens superior e esquerda $3 \mathrm{~cm}$, margens inferior e direita $2 \mathrm{~cm}$, entrelinhas 1,5, fonte Times New Roman, tamanho 12, com exceção das ilustrações, tabelas, notas e citações diretas em recuo, cujas fontes devem apresentar tamanho 10, entradas de parágrafo, 1,25, a partir da margem. O texto deve ser justificado, exceto as referências, que são alinhadas à margem esquerda. Os artigos devem apresentar extensão de 15 a 25 páginas.

As páginas devem ser numeradas à margem superior direita.

Para as tabelas e ilustrações (fotografias, mapas, gráficos, quadros, fluxogramas organogramas, diagramas, esquemas, entre outras), é necessário que os arquivos originais sejam enviados, também, em arquivo digital, separadamente. As imagens digitalizadas devem apresentar resolução de 300 dpi. As ilustrações e tabelas devem ser numeradas de acordo com suas respectivas referências no corpo do texto, e os títulos, escritos sem abreviações, apresentando a fonte de referência em tamanho 10 e entrelinhas simples. Evitar o uso de palavras como "abaixo", "acima” para referir-se a tabelas e ilustrações.

Todas as tabelas e ilustrações devem apresentar a fonte de origem dos dados. Símbolos e fórmulas matemáticas devem ser enviados em jpg (imagem) com resolução mínima de 300 dpi.

Ainda, de acordo com a NBR 6022 (ASSOCIAÇÃO BRASILEIRA DE NORMAS TÉCNICAS, 2003), a publicação deve ser constituída por: 
a) Elementos pré-textuais

Título e subtítulo (se houver): devem figurar na página de abertura do texto, separados por dois-pontos e na língua do texto.

Resumo na língua do texto: deve ser apresentado na terceira pessoa do singular, na voz ativa e redigido em um único parágrafo, com extensão de 100 a 250 palavras. Deve conter: o contexto, o objetivo e a metodologia e os principais resultados do estudo.

Palavras-chave na língua do texto: palavras que representam os principais assuntos tratados no texto (entre 3 a 5 palavras); devem figurar logo abaixo do resumo, antecedidas da expressão Palavras-chave:, separadas entre si por ponto e finalizadas também por ponto.

Observação: informações sobre o(s) Nome(s) do(s) autor(es), acompanhado(s) da titulação do(s) autor(es), local de trabalho, endereço postal completo, função que exerce $(\mathrm{m})$ e e-mail não devem ser colocadas no texto, mas sim devem ser postadas completas no cadastro dos autores.

b) Elementos textuais

Introdução: apresenta a delimitação do assunto, objetivos da pesquisa e outros elementos sobre o tema explanado.

Desenvolvimento: parte principal do texto, que apresenta de forma ordenada o assunto tratado. Pode ser dividido em seções e subseções, de acordo com o tema abordado.

Conclusão: aborda os resultados da pesquisa de forma a responder às questões apresentadas na introdução; usa-se como título a palavra Conclusão.

c) Elementos pós-textuais

Título e subtítulo (se houver), em língua estrangeira.

Resumo em língua estrangeira: versão do resumo na língua do texto para o idioma de divulgação internacional, utilizando as mesmas características (em inglês Abstract, em espanhol Resumen, em francês Résumé).

Palavras-chave em língua estrangeira: versão na língua do texto para a mesma língua estrangeira do resumo (em inglês Keywords, em espanhol Palabras clave, em francês Mots-clés). 
Nota(s) explicativa(s): deve(m) ser utilizada(s) apenas para comentários e/ou explicações que não possam ser incluídas no texto, não para referências. Precisa(m) ser elaborada(s), ao final do artigo, antecedendo a lista de referências, numeradas sequencialmente.

Referências: devem ser colocadas ao final do trabalho, classificadas em ordem alfabética pelo sobrenome do autor, com alinhamento à margem esquerda, entrelinhas simples e espaçamento duplo entre elas, observando-se a NBR 6023 (ASSOCIAÇÃO BRASILEIRA DE NORMAS TÉCNICAS, 2002).

Para as citações, deve ser observada a NBR 10520 (ASSOCIAÇÃO BRASILEIRA DE NORMAS TÉCNICAS, 2002).

As palavras em língua estrangeira devem estar em itálico. Os títulos devem ser numerados em números arábicos, da Introdução à Conclusão.

Para ciência dos autores, informarmos que o material editado (originais, rascunhos, miolo) permanecerá armazenado na Editora Unoesc pelo período de um ano, após ser publicado, conforme Política Editorial, sendo posteriormente reciclado.

\section{SUBMITION REGULATIONS}

The articles and review submitted to the periodic RACE (Magazine of Administration, Accountability and Economy) should obey the criteria here described.

a) Each author can submit 1 (one) article per year to the periodic.

b) The accuracy of the references and the ideas expressed and/or defended in the text are the entire responsibility of the authors; they, when submitting the article, must accept the Copyright Statements.

c) Texts in Portuguese and in English will be accepted.

d) The text must pass through linguistic revision before being submitted.

e) The periodic's Scientific Editor and Publisher Unoesc are not responsible for the misplacement or possibe loss of materials, so the author must keep copies of the original text.

f) The works must be submitted in the Maganize's eletronic mail: http://editora.unoesc.edu.br/index.php/race/index in .doc format.

g) The article must be unpublished, fit on the focus, scope and editorial line of the Magazine, be in conformity with ABNT guidelines and it cannot be under avaluation in other magazine concomitantly. 
Race Magazine does not receive articles only on literature review, since the submitted texts must admit or dense theoretical studies or theoretical and empirical studies which contribute to the areas of Administration, Accountability and/or Economy.

The texts are submitted to the aproval of the editorial board, omitting the author's and the evaluator's names during the double blind review process (the author does not know who the evaluator is and the evaluator does not know the author either).

After the process, in case it is necessary, the evaluators will propose alterations, aiming to the improvement of the work, with the objective of publishing it. If the alterations are not done to the satisfaction and within the specified period, the evaluator can reject the article.

After the evaluation, the articles will be directed to the Publisher to the revision, normalization and formatting processes, according to ABNT guidelines. The authors' and the consultants' job will not be paid.

All the authors/doctors of the submitted article compromise automatically to act as evaluators of other articles submitted to the magazine of the respective knowledge areas.

The Magazine is published in electronic format (PDF), available by Internet in the Magazine's website and/or in the indexer(s)' website(s).

The Magazine will allow access to the articles, the reviews and the other texts, not authorizing any commercialization and/or data alteration. Thus, the author(s) is (are) aware of the cession of their publishing copyright to the Magazine.

The articles should be written in A4 format, top and left margin $3 \mathrm{~cm}$, bottom and right margin $2 \mathrm{~cm}$, line space 1,5, Times New Roman, size 12, space, except illustrations, charts, notes and direct quotes indented, that must have font size 10, paragraph, 1,25 from the margin. The text must be justified, except the references, which are aligned to the left margin. The articles must have 15 to 25 pages.

The pages must be numbered in the top right margin.

To the charts and illustrations (pictures, maps, graphics, boards, flowcharts, organograms, diagrams, schemes, and others), it is necessary that the original files are sent, as well, in digital file, separately. The scanned images must have resolution of 300 dpi. The illustrations and charts must be numbered according to their corresponding references in the body of the text, and the titles, written without abbreviation, with the reference font size 10 and simple line space. Avoid the use of words like "below", "above" to refer to charts and illustrations.

All the charts and illustrations must present the source of the data. Symbols and math formulas must be sent in jpg (image) with minimum resolution of $300 \mathrm{dpi}$.

Furthermore, according to NBR 6022 (BRAZILIAN ASSOCIATION OF TECHNICAL NORMS, 2003), the publishing must be constituted by:

a) Pre-textual elements 
Title and subtitle (if there is) must figure the opening page of the text, separated by colon and in the text language.

Abstract in the text language: it must be presented on third person singular, active voice and written only in one paragraph, 100 to 250 words in length. It must contain: the context, the objective and the methodology and the main results of the study.

Keywords in the text language: words that represent the main issues addressed in the text (3 to 5 words); they must be right above the abstract, preceded by the expression Keywords:, separated by a period and ended also by a period.

Observations: information about the author(s)'s name(s), with the author(s)'s qualification, workplace, full address, function they hold and e-mail should not be in the text; they must be posted complete in the authors' record.

\section{b) Textual elements}

Introduction: it shows the delimitation of the issue, objectives of the research and other elements about the topic.

Development: main part of the text, it shows, in an orderly manner, the addressed topic. It can be divided into sections and subsections, according to the topic discussed.

Conclusion: it addresses the results of the research in order to answer the questions presented in the introduction; it is used, as a title, the word Conclusion.

c) Post-textual elements

Title and subtitle (if there is), in foreign language.

Abstract in foreign language: version of the abstract in the text language to the language of international diffusion, using the same characteristics (in English Abstract, in Spanish Resumen, in French Résumé).

Keywords in foreign language: version in the text language to the same foreign language of the abstract (in English Keywords, in Spanish, Palabras clave, in French Mots-clés).

Explanatory notes: they must be used only to comments and/or explantions that cannot be included in the text, not to references.

They need to be elaborated in the end of the article, preceding the references list, numbered sequentially.

References: they must be in the end of the work, classified in alphabetical order by the author's last name, aligned to the left margin, line space simple and double space between them, observing the NBR 6023 (BRAZILIAN ASSOCIATION OF TECHNICAL NORMS, 2002). 
To quotes, it is necessary to observe the NBR 10520 (BRAZILIAN ASSOCIATION OF TECHNICAL NORMS, 2002).

The words in foreign language must be in italic. The titles must be numbered in arabic numbers, from the Introduction to the Conclusion.

For the authors' knowledge, we inform that the edited material (originals, drafts, content) will remain stored on Publisher Unoesc for one year, after being published, according to the Editorial Policy, and being, subsequently, recycled. 
